\title{
Polycyclic aromatic hydrocarbons (PAH) in Portuguese educational settings: a comparison \\ between preschools and elementary schools
}

\author{
Klara Slezakova, Marta Oliveira, Joana Madureira, Eduardo de Oliveira \\ Fernandes, Cristina Delerue-Matos, Simone Morais \& Maria do Carmo \\ Pereira
}

\begin{abstract}
The aim of this study was to determine levels and risks due to inhalation exposure to polycyclic aromatic hydrocarbons (PAH) in different educational settings, namely for 3- to 5- year-old and 6- to 10year-old children. Eighteen PAH (16 priority designated by US Environmental Protection Agency (USEPA) and dibenzo[a,I]pyrene and benzo[j]fluoranthene) were simultaneously collected in indoor and outdoor air at two Portuguese preschools (PS1-PS2) and five elementary schools (ES1-ES5) from March to May 2014. Indoor concentrations at PS and ES were significantly different, with total levels ( $\mathrm{PAHs}$ ) $0.721-15.9 \mathrm{ng} / \mathrm{m} 3$ at PS1-PS2 and 5.03-23.6 ng/m3 at ES1-ES5. The corresponding outdoor concentrations were, respectively, $1.22-32.7 \mathrm{ng} / \mathrm{m3}$ and $2.6-31.5 \mathrm{ng} / \mathrm{m} 3$. Polycyclic aromatic hydrocarbons with 2-3 aromatic rings were predominantly emitted by indoor sources, while compounds with 4-6 aromatic rings were mainly generated by infiltration of ambient PAH pollution to indoors. Excess lifetime risks of lung cancer exceeded the World Health Organization (WHO) designated guideline of 10-5 in both types of schools (15-42-fold at PS; 15-52-fold at ES). However, total (sum of indoor and outdoor exposure) incremental lifetime cancer risks (ILCR) were below the USEPA level of 10-6 at all studied institutions and thus considered negligible. Finally, ILCR due to indoor exposure represented $60-75 \%$ and $70-85 \%$ of the total ILCR at PS and ES, respectively, thus indicating the need for development and implementation of indoor air quality guidelines in educations settings.
\end{abstract}




\section{Introduction}

Polycyclic aromatic hydrocarbons (PAH) are organic contaminants containing at least two aromatic rings that are ubiquitously found in all environmental matrices (air, soil, and water). Polycyclic aromatic hydrocarbons $(\mathrm{PAH})$ are organic contaminants containing at least two aromatic rings that are ubiquitously found in all environmental matrices (air, soil, and water).

These chemicals are produced by incomplete combustion of organic material such as coal, oil, or wood. In urban areas, PAH are mostly emitted from vehicle exhausts and other manmade sources such as power plants, industrial and waste treatment processes, and from biomass combustions (Ravindra et al., 2008; Samburova et al., 2016; Sarigiannis et al., 2015). The relevant indoor sources are tobacco smoke, cooking, combustion process (candle, fuels), and infiltration of outdoor emissions (Chen et al., 2012; Qi et al., 2014; Slezakova et al., 2014a; Shen et al., 2012; Wu et al., 2015). As PAH exhibit semivolatile properties, these compounds are distributed between vapor phase and adsorbed onto particles predominantly associated with fine fractions such as PM2.5 (aerodynamic diameter below 2.5 $\mu \mathrm{m}$ ) or PM1 (aerodynamic diameter <1 $\mu \mathrm{m}$ ) (Mesquita et al., 2014; Sánchez-Soberón et al. 2016; Slezakova et al., 2013a, 2013b). The partitioning between both phases then significantly impacts fate, removal and transport of PAH in the atmosphere (Dvorská et al., 2012) as well their entry into humans. For general population, breathing air (indoor and ambient) and consumption of food containing PAH are major routes of PAH exposure (Elabbas et al., 2014; Pampanin et al., 2016). The PAH are highly lipophilic such that human bioavailabil- ity is significant (Sarigiannis et al., 2015), and these compounds were detected in nearly all internal organs (principally in adipose tissues) (Abdel-Shafy \& Mansour, 2016). A number of PAH are mutagenic, genotoxic (Annesi- Maesano et al., 2007; Tuntawiroon et al., 2007) and considered as endocrine disrupting chemicals (Berg et al., 2016; WHO, 2013). Cancer is the major disease concern for PAH exposure (Abdel-Shafy \& Mansour, 2016; Boström et al., 2002) with several individual congeners being designated as carcinogenic (probable and/or possible ones) (IARC, 2002, 2010).

Due to their susceptibility (Burtscher \& Schüepp, 2012; Foos et al., 2008), potential PAH health consequences are especially important for children. The period spent in schools such as preschools and kin- dergartens represents on a daily basis approximately $30 \%$ of child's time, which increases the interest to better understand exposure-health outcomes rela- tionship (Annesi-Maesano et al., 2007, 2013; Bae et al., 2010; Madureira et al., 2015). Thus, a number of investigators determined PAH levels in schools, but the current understanding is far from compre- hensive. Further, most of the existing knowledge originates from the studies conducted in environ- ments for 6-10/11-year-old students (i.e., primary/ elementary levels of education) (Alves et al., 2014; Carpenter \& Bushkin-Bedient, 2013; Cirillo et al., 2006; Jovanović et al., 2014; Jyethi et al., 2014; Krugly et al., 2014; Moshammer \& Neuberger, 2003; Romagnoli et al., 2014; Ruchirawat et al., 2006, 2007; Tuntawiroon et al., 2007), whereas data 
for nurseries, day care centers and PS environments are rather scarce (Eiguren-Fernandez et al., 2007; Oliveira et al., 2015, 2016a, 2016b). Moreover, chil- dren interact with environment surrounding them in a unique way. The activity patterns and behavior of young children and infants are different from those of older children and adolescents (Cohen Hubal et al., 2000; Mielgo-Ayuso et al., 2016), and thus, the reported data and estimated risks may not be applicable to infants and younger children.

The aim of this study was to determine levels and risks of $16 \mathrm{PAH}$ designated by US Environmental Protection Agency (USEPA) as priority ones, in addi- tion to benzo[j]fluoranthene and dibenzo[a,I]pyrene in different educational settings. Levels and composi- tional profiles of PAH in indoor and outdoor air of two preschools (3-5 year pupils) and five elementary schools (6- to 10-year-old children) were character- ized. The contribution of ambient PAH to indoor levels was assessed. Risks for two different age groups of students (3-5 and 6-10 year old) were estimated according to World Health Organization (WHO) quantitative risk assessment methodology (WHO, 1987, 2000) and USEPA risk approach method (USEPA, 2016).

\section{Materials and methods}

\section{Characterization of selected schools}

Particulate matter (PM)2.5-bound PAH were col- lected continuously from March to May 2014 at two preschools (3- to 5-year-old children; PS1-PS2) and five elementary schools (6- to 10-year- old students; ES1-ES5) situated in Porto, Portugal. All schools were considered as urban sites with traffic emissions the predominant pollution source in the respective areas (Pereira et al., 2007; Slezakova et al., 2013b).).

\section{Sampling}

At all educational institutes, children daily sche- dules and conducted activities were recorded (Table $1 \mathrm{~S}$ of the supplementary material). Indoor PM2.5-bound PAH $(n=42)$ were sampled in class- rooms as it was the microenvironment where stu- dents were present most of their time (Table 1S). Sampling was conducted daily during three con- secutive weekdays (Tuesday-Thursday); Mondays and Fridays were avoided as students' programs were frequently irregular. Sample collection was performed at each school simultaneously at two classrooms; in total, 14 rooms were assessed. Relevant details of each room including layout and materials were also recorded (Table 1S). School personnel reported daily information con- cerning any unusual emission source and/or unty-

pical indoor occurrences. PM2.5 sampling was conducted based upon the USEPA IP-10A method (USEPA, 1990). The sampling setup consisted of a personal environmental monitor (PEM ${ }^{\text {TM }}$ S SKC Ltd., Dorset, UK), that is, single-stage impactor (PM2.5) connected with personal air sampling pump (AirChek® 2000; SKC Ltd., Dorset, UK); samples were collected for a period of $24 \mathrm{hr}$ with flow rate 0.12 
$\mathrm{m} 3 / \mathrm{hr}$. This setup was used as it was appropriate for indoor sampling (i.e., confined space with limited air exchange) and was almost noise free. The collection devices were placed approximately at $1 \mathrm{~m}$ above the surface and mini- mum $1 \mathrm{~m}$ from any obstacles (doors, wall, and corners), avoiding any unnecessary obstructions in the rooms and maintaining all safety precautions. Concurrently with indoor sampling, particulate bound PAH were collected outdoors (in ambient air; $\mathrm{n}=21$ ). The sampling equipment (constant-flow sam- plers, model Bravo H2 supplied by TCR TECORA, Paris France combined with PM2.5 EN LVS sampling head in agreement with norm EN14907) suitable for outdoor meteorological conditions was situated in open zones of school yards using an air flow rate of $2.3 \mathrm{~m} 3 / \mathrm{hr}$.

Polytetrafluoroethylene (PTFE) membrane filters (SKC Ltd., Dorset, UK; $2 \mu \mathrm{m}$ porosity, $\varnothing 37 \mathrm{~mm}$ for indoor sampling and $\varnothing 47 \mathrm{~mm}$ for ambient air sampling), which were compatible with the respec- tive indoor and outdoor samplers, were used for PM2.5 collection. After gravimetric mass determina- tion that was conducted according to Oliveira et al. (2016a, 2016b) and Slezakova et al. (2011), filters were stored in PVC containers in freezer $\left(-18^{\circ} \mathrm{C}\right)$ for subsequent chemical analysis. 
Table 1. Levels of PM 2.5 -bound PAHs at studied preschools (PS1, PS2) and primary schools. (ES1-ES5). PAHs levels ( $\left.\mathrm{ng} / \mathrm{m}^{3} ; \mathrm{n}=63\right)$ are presented as sums of individual compounds according to the number of aromatic rings, i.e. groups with 2, 3, 4, 5 and 6 ring.

\begin{tabular}{|c|c|c|c|c|c|c|c|}
\hline Indoors & $n=42$ PS1 & PS2 & ES1 & ES2 & ES3 & ES4 & ES5 \\
\hline 2 -rings & $\begin{array}{c}0.140 \\
\left(2.01 \times 10^{-2}-0.939\right)\end{array}$ & $\begin{array}{c}0.137 \\
\left(6.35 \times 10^{-2}-0.413\right)\end{array}$ & $\begin{array}{c}0.110 \\
(0.101-0.123)\end{array}$ & $\begin{array}{c}0.223 \\
(0.182-0.269)\end{array}$ & $\begin{array}{c}0.264 \\
(0.195-0.328)\end{array}$ & $\begin{array}{c}0.275 \\
(0.142-0.431)\end{array}$ & $\begin{array}{c}0.263 \\
(0.192-0.335)\end{array}$ \\
\hline 3 -rings & $\begin{array}{c}0.383 \\
\left(4.42 \times 10^{-2}-0.636\right) \\
\end{array}$ & $\begin{array}{c}1.46 \\
(0.234-3.32) \\
\end{array}$ & $\begin{array}{c}5.83 \\
(4.87-6.67) \\
\end{array}$ & $\begin{array}{c}9.44 \\
(7.76-11.1) \\
\end{array}$ & $\begin{array}{c}5.43 \\
(3.51-7.33) \\
\end{array}$ & $\begin{array}{c}5.79 \\
(4.40-7.16) \\
\end{array}$ & $\begin{array}{c}1.85 \\
(1.41-2.27) \\
\end{array}$ \\
\hline 4-rings & $\begin{array}{c}1.12 \\
(0.129-2.89)\end{array}$ & $\begin{array}{c}0.356 \\
(0.282-0.548)\end{array}$ & $\begin{array}{c}1.06 \\
(0.534-1.57)\end{array}$ & $\begin{array}{c}0.582 \\
(0.509-0.650\end{array}$ & $\begin{array}{c}1.10 \\
(0.568-1.63)\end{array}$ & $\begin{array}{c}1.16 \\
(0.540-1.78)\end{array}$ & $\begin{array}{c}0.321 \\
(0.262-0.378)\end{array}$ \\
\hline 5-rings & $\begin{array}{c}3.25 \\
(0.151-9.63) \\
\end{array}$ & $\begin{array}{c}1.64 \\
(0.586-3.72) \\
\end{array}$ & $\begin{array}{c}3.97 \\
(3.92-4.02)\end{array}$ & $\begin{array}{c}1.96 \\
(1.82-2.09)\end{array}$ & $\begin{array}{c}7.10 \\
(3.49-10.8)\end{array}$ & $\begin{array}{c}3.61 \\
(2.72-4.52)\end{array}$ & $\begin{array}{c}2.09 \\
(1.95-2.25)\end{array}$ \\
\hline 6 -rings & $\begin{array}{c}1.29 \\
\left(9.21 \times 10^{-2}-3.44\right) \\
\end{array}$ & $\begin{array}{c}0.606 \\
(0.309-1.92) \\
\end{array}$ & $\begin{array}{c}1.60 \\
(4.49-1.73) \\
\end{array}$ & $\begin{array}{c}0.731 \\
(0.675-0.762) \\
\end{array}$ & $\begin{array}{c}2.55 \\
(1.29-3.81) \\
\end{array}$ & $\begin{array}{c}1.38 \\
(1.09-1.71) \\
\end{array}$ & $\begin{array}{c}0.787 \\
(0.734-0.817) \\
\end{array}$ \\
\hline$\Sigma_{\text {PAHs }}$ & $\begin{array}{c}6.18 \\
(0.721-15.9) \\
\end{array}$ & $\begin{array}{c}4.20 \\
(2.60-7.77) \\
\end{array}$ & $\begin{array}{c}12.6 \\
(11.0-14.0) \\
\end{array}$ & $\begin{array}{c}12.9 \\
(11.4-14.5) \\
\end{array}$ & $\begin{array}{c}16.4 \\
(9.24-23.6) \\
\end{array}$ & $\begin{array}{c}12.2 \\
(9.23-15.2) \\
\end{array}$ & $\begin{array}{c}5.31 \\
(5.03-5.58) \\
\end{array}$ \\
\hline$\sum_{\text {PAHscarc }}$ & $\begin{array}{c}4.49 \\
(0.425-12.3)\end{array}$ & $\begin{array}{c}2.23 \\
(1.25-6.00)\end{array}$ & $\begin{array}{c}5.07 \\
(4.96-5.17)\end{array}$ & $\begin{array}{c}2.69 \\
(2.48-2.87\end{array}$ & $\begin{array}{c}9.17 \\
(4.72-13.6)\end{array}$ & $\begin{array}{c}4.76 \\
(3.76-5.80)\end{array}$ & $\begin{array}{c}2.83 \\
(2.63-3.03)\end{array}$ \\
\hline Outdoors & $\mathrm{n}=21 \mathrm{PS} 1$ & PS2 & ES1 & ES2 & ES3 & ES4 & ES5 \\
\hline 2 -rings & $\begin{array}{c}0.755 \\
\left(2.02 \times 10^{-2}-8.77\right) \\
\end{array}$ & $\begin{array}{c}7.08 \times 10^{-2} \\
\left(2.51 \times 10^{-2}-0.150\right) \\
\end{array}$ & $\begin{array}{c}9.80 \times 10^{-2} \\
\left(6.30 \times 10^{-2}-0.128\right)\end{array}$ & $\begin{array}{c}9.75 \times 10^{-2} \\
\left(8.21 \times 10^{-2}-0.118\right) \\
\end{array}$ & $\begin{array}{c}0.159 \\
\left(4.11 \times 10^{-2}-0.254\right)\end{array}$ & $\begin{array}{c}0.144 \\
(0.112-0.170) \\
\end{array}$ & $\begin{array}{c}3.78 \times 10^{-2} \\
\left(2.53 \times 10^{-2}-5.15 \times 10^{-2}\right) \\
\end{array}$ \\
\hline 3 -rings & $\begin{array}{c}1.24 \\
\left(3.382 .01 \times 10^{-2}-2.34\right) \\
\end{array}$ & $\begin{array}{c}1.16 \\
(0.206-2.61) \\
\end{array}$ & $\begin{array}{c}2.88 \\
(1.63-3.86) \\
\end{array}$ & $\begin{array}{c}2.78 \\
(2.54-2.99) \\
\end{array}$ & $\begin{array}{c}5.25 \\
(1.85-8.01) \\
\end{array}$ & $\begin{array}{c}1.27 \\
(0.662-1.73) \\
\end{array}$ & $\begin{array}{c}1.31 \\
(0.653-1.12) \\
\end{array}$ \\
\hline 4 4-rings & $\begin{array}{c}2.15 \\
(0.271-8.43) \\
\end{array}$ & $\begin{array}{c}0.590 \\
(0.295-1.79) \\
\end{array}$ & $\begin{array}{c}1.82 \\
(0.347-4.77) \\
\end{array}$ & $\begin{array}{c}0.622 \\
(0.370-0.922) \\
\end{array}$ & $\begin{array}{c}1.67 \\
(1.64-1.71) \\
\end{array}$ & $\begin{array}{c}2.93 \\
(0.915-6.82) \\
\end{array}$ & $\begin{array}{c}0.730 \\
(0.549-0.968) \\
\end{array}$ \\
\hline 5 -rings & $\begin{array}{c}4.36 \\
(0.532-17.9)\end{array}$ & $\begin{array}{c}2.03 \\
(0.751-5.01)\end{array}$ & $\begin{array}{c}6.93 \\
(1.03-17.7)\end{array}$ & $\begin{array}{c}2.73 \\
(1.22-4.73)\end{array}$ & $\begin{array}{c}4.29 \\
(3.45-5.76)\end{array}$ & $\begin{array}{c}9.04 \\
(1.99-15.2)\end{array}$ & $\begin{array}{c}3.20 \\
(2.73-4.09)\end{array}$ \\
\hline 6-rings & $\begin{array}{c}1.56 \\
(0.107-5.87) \\
\end{array}$ & $\begin{array}{c}0.693 \\
(0.325-2.16)\end{array}$ & $\begin{array}{c}2.08 \\
(0.347-5.18)\end{array}$ & $\begin{array}{c}0.874 \\
(0.384-1.57)\end{array}$ & $\begin{array}{c}1.42 \\
(1.12-1.96) \\
\end{array}$ & $\begin{array}{c}2.48 \\
(0.701-4.46)\end{array}$ & $\begin{array}{c}1.06 \\
(0.925-1.28)\end{array}$ \\
\hline$\sum_{\mathrm{PAHS}}$ & $\begin{array}{c}10.1 \\
(1.22-32.7)\end{array}$ & $\begin{array}{c}4.55 \\
(2.60-7.77)\end{array}$ & $\begin{array}{c}13.8 \\
(3.49-31.5)\end{array}$ & $\begin{array}{c}7.10 \\
(4.65-10.3)\end{array}$ & $\begin{array}{c}12.8 \\
(11.2-14.8)\end{array}$ & $\begin{array}{c}15.9 \\
(5.48-27.0)\end{array}$ & $\begin{array}{c}6.34 \\
(5.00-8.42)\end{array}$ \\
\hline$\sum_{\text {PAHscarc }}$ & $\begin{array}{c}6.82 \\
(0.776-24.8)\end{array}$ & $\begin{array}{c}2.70 \\
(1.33-7.82)\end{array}$ & $\begin{array}{c}5.07 \\
(4.96-5.17)\end{array}$ & $\begin{array}{c}2.69 \\
(2.48-2.87)\end{array}$ & $\begin{array}{c}9.17 \\
(4.72-13.6)\end{array}$ & $\begin{array}{c}4.76 \\
(3.76-5.80)\end{array}$ & $\begin{array}{c}2.83 \\
(2.63-3.03)\end{array}$ \\
\hline
\end{tabular}




\section{Extraction and quantification of PAH}

Extraction and determination of PAH were conducted in agreement with validated analytical procedures (Castro et al., 2009, 2011). Additional information is provided in Supplementary Material (section 1S).

\section{Risk analysis}

Risks due to inhalation exposure to PM2.5-bound PAH were assessed by toxicity equivalent concentrations (B[a]Peq) based upon toxicity of benzo[a]pyrene. Values of toxicity equivalency factors (TEF) proposed by Nisbet and LaGoy (Boström et al., 2002) were used. Excess lifetime risk of lung cancer was then estimated by quantitative risk assessment methodology using unit risk value of $8.7 \times 10-5$ (ng/m3)-1 (WHO, 1987,2000$)$.

\section{Calculation of incremental lifetime cancer risks}

(ILCR) was determined based upon USEPA meth- odology (Region III Risk-based Concentration Table) (USEPA, 2016). USEPA designates that

ILCR between $10-6$ and 10-4 indicate potential risks; values lower than 10-6 are considered as safe, whereas potentially high risks are denoted by values greater than 10-4 (USEPA, 1989). The complete methodology and ILCR calculations are described in Oliveira et al. (2016a, 2016b), but for reader's convenience, Table $2 S$ provides an exam- ple of ILCR calculations; default parameters are shown in Tables $3 \mathrm{~S}$ and $4 \mathrm{~S}$.

\section{Statistical analysis}

Statistical analysis was performed according to Oliveira et al. (2016a, 2016b). SPSS (IBM SPSS Statistics 20) and Statistica software (v. 7, StatSoft Inc., USA) were used. Comparison of means was conducted through nonparametric Mann -Whitney U-test, since normal distribution was not observed by Shapiro-Wilk's test. The criterion for significance was set at $p<0.05$.

\section{Results}

\section{PS and ES characteristics}

The selected schools were constructed between 1940 (PS1) and 1980 (ES1); all were refurbished during the last decade (2004-2008). Number of students ranged between 44 and 173 for PS, whereas it was between 280 (ES4) and 420 (ES5) for ES. Further information regarding possible emission (indoor and outdoor) sources at schools, heating systems, relevant equipment/materials, and cleaning schedules is summarized in Table 5S. Regarding the ventilation, all classrooms were naturally ventilated by opening doors and windows, as no mechanical systems existed. Overall, the ventilation of 
rooms was not frequent. Typically, the windows were rarely opened when classes were in sessions (only at ES4 and ES5 for couple of minutes), whereas at ES2, ES4, and ES5 rooms were regularly ventilated during recess periods. At both PS, ventilation was always conducted at the beginning (for 10-15 $\mathrm{min}$ ) and at the end (15-20 min) of each day. In all schools, windows were always opened when rooms were cleaned which was usually at the end of the day; the durations lasted between couple of min until half hour at ES5.

\section{PAH levels}

The levels of PM2.5-bound PAH at two PS and five ES are summarized in Table 1. The concentrations are presented for groups of congeners according to the number of aromatic rings (2-6 aromatic rings). Total levels (i.e., minimal-maximal) of $\sum \mathrm{PAH}$ indoors ranged from 0.7 (PS1) to $23.6 \mathrm{ng} / \mathrm{m} 3$ (ES3), whereas the mean concentrations were between 4.2 (PS2) and $16.4 \mathrm{ng} / \mathrm{m} 3$ (ES3). The indoor levels of $\Sigma \mathrm{PAHs}$ at PS were significantly different from those observed at ES. The highest $\Sigma \mathrm{PAH}$ were detected at ES3 3 and fourfold higher than at PS1 and PS2, respectively. Overall, indoor $\triangle \mathrm{PAH}$ were relatively similar at ES1-ES4 with the only exception to ES5 that exhibited 2-3-fold lower concentrations. Although no specific reasoning was found for the lower concentrations at ES5, it should be noted that classrooms at this school were more frequently ventilated, whereas at the same time, $\mathrm{PAH}$ ambient pollution levels were similarly low.

The compositional profiles between all institutions characterized in this study were similar to some extent. At both PS 5-6 rings, congeners were the predominant groups of PAH indoors (74\% of $\sum$ PAHs at PS1 and 53\% at PS2). However, congeners with three rings (acenaphthylene, acenaphetene, fluorene, phenanthrene, and anthracene) accounted for $6 \%$ of indoor $\Sigma \mathrm{PAH}$ at PS1, whereas it was $35 \%$ at PS2. Similar to the latter, in indoor air of ES, congeners with three rings were largely abundant (ranging between $33 \%$ at ES3 and $77 \%$ of $\Sigma$ PAHs at ES2) predominantly due to high levels of acenaphthylene which was the greatest (36-62\% of $\left.\sum \mathrm{PAH}\right)$, or the second most $(22-24 \%$ at ES3 and ES5) abundant indoor compound. Finally, $\mathrm{PAH}$ with two rings (i.e., naphthalene) were the least abundant congener in indoor air of both PS and ES (2-3\% of $\sum$ PAH at PS1-PS2; $\approx 2 \%$ at ES1-ES5).

The concentration ranges of PAH in outdoor air of ES and PS are also presented in Table 1. The results showed that mean indoor versus outdoor $\triangle \mathrm{PAH}$ of each school were not markedly different with the exception to PS1 and ES2 where indoor $\Sigma$ PAH were approximately twofold higher than outdoors. At both these institutions, lunches were directly cooked at the premises (i.e., in school canteen), thus potentially leading to overall higher indoor PAH pollution (compared with ambient air).

Compositional profiles of PAH in outdoor air exhibited some similarities between PS and ES with 5-6 
rings compounds representing the most abundant compounds (60\% of $\sum \mathrm{PAH}$ at both PS1 and PS2; mean of $60 \%$ at ES: i.e., $45 \%$ at ES3-73\% at ES4). Indoor to outdoor (I/O) ratios of PAH at all educational settings are illustrated in Figure 1. PAH with 2-3 rings exhibited $\mathrm{I} / \mathrm{O}$ higher than unity (with exception to PS1) suggesting predominantly indoor origin (emissions sources and occupants activities). $\mathrm{I} / \mathrm{O}$ ratios for $\mathrm{PAH}$ with 4, 5-6 aromatic rings were $<1$ at all schools (except for ES3) indicating outdoor origin.

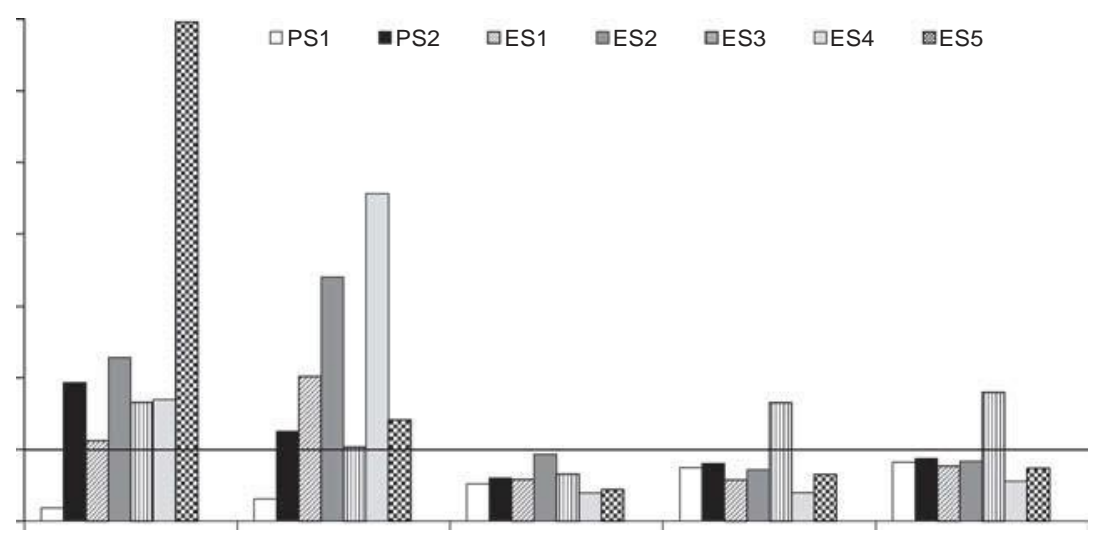

Figure 1. Indoor to outdoor (I/O) ratios of PM2.5-bound PAHs at preschools (PS1-PS2) and elementary schools (ES1-ES5). Ratios are demonstrated for congeners according to their number of aromatic rings, that is, groups of PAHs with $2,3,4,5$, and 6 rings.

Risk assessment

Benzo[a]pyrene equivalent concentrations (B[a]Peq) are summarized in Table 2. Overall, the total $\mathrm{B}[\mathrm{a}] \mathrm{Peq}$ of $18 \mathrm{PAH}\left(\sum \mathrm{B}[\mathrm{a}] \mathrm{Peq}\right)$ in indoor air of both PS $(4,700-13,030 \mathrm{pg} / \mathrm{m} 3)$ were up to twofold lower than at ES (5 $625 \mathrm{pg} / \mathrm{m3}$ at ES2 - $21730 \mathrm{pg} / \mathrm{m} 3$ at ES3). The excess lifetime risk of lung cancer was estimated considering that 3- to 5-year-old children spent typically $6 \mathrm{hr}$ of their school time indoors (1.5hr outdoors), whereas it was 6-hr and 1-hr indoors and outdoors, respectively, for students of ES. Thus, the corresponding lung cancer risks were $4.18 \times 10-4$ and $1.52 \times 10-4$ at two PS (indoors: $3.31 \times 10-4$ at PS1 and $1.21 \times 10-4$ at PS2; outdoors $8.71 \times 10-5$ at PS1 and $3.13 \times 10-5$ at PS2) and a range of $1.49 \times 10-4-5.17 \times 10-4$ at five ES (indoors: $1.22 \times 10-4$ at ES2 - 4.73×10-4 at ES3; outdoors: $2.69 \times 10-$ 5 at ES2 - 6.45×10-5 at ES1). At all seven institutions evaluated in this study excess lifetime cancer risks (calculated with the mean concentrations) surpassed (from 15-fold at PS2/ES2 up to 52-fold at ES3) the level of 10-5 designated by WHO (Boström et al., 2002). 
Table 2. Toxicity equivalent concentrations based on toxicity of benzo[a]pyrene (B[a]Peq) of $\mathrm{PM}_{2.5}-\mathrm{bound} \mathrm{PAHs}\left(\mathrm{pg} / \mathrm{m}^{3}\right.$ ) at two preschools (PS1, PS2) and 5 primary schools (ES1-ES5). Concentrations are presented according to the number of aromatic rings, i.e. groups of PAHs with 2, 3, 4, 5 and 6 rings.

\begin{tabular}{lccccccc}
\hline Indoors & PS1 & PS2 & ES1 & ES2 & ES3 & ES4 \\
\hline 2-rings & $7.69 \times 10^{-2}$ & 0.137 & 0.110 & 0.223 & 0.264 & 0.275 & 0.263 \\
3-rings & 0.262 & 1.59 & 5.83 & 9.44 & 5.43 & 5.79 & 1.85 \\
4-rings & 14.5 & 5.71 & 9.94 & 9.56 & 20.3 & 10.5 \\
5-rings & 8830 & 4730 & 11930 & 5575 & 21560 & 10210 & 6.08 \\
6-rings & 4180 & 33.3 & 83.4 & 31.0 & 140 & 67.8 & 37.2 \\
L & 13030 & 4770 & 12030 & 5625 & 21730 & 10290 & 6492 \\
Outdoors & & & & & & \\
2-rings & 0.365 & $7.08 \times 10^{-2}$ & $9.80 \times 10^{-2}$ & $9.75 \times 10^{-2}$ & 0.159 & 0.144 & $3.78 \times 10^{-2}$ \\
3-rings & 0.356 & 1.26 & 2.88 & 2.78 & 5.25 & 1.27 & 1.31 \\
4-rings & 34.0 & 12.9 & 42.4 & 8.49 & 20.2 & 34.5 & 12.3 \\
5-rings & 11950 & 5715 & 17610 & 7361 & 12130 & 22330 & 9000 \\
6-rings & 4030 & 35.0 & 118 & 46.6 & 77.4 & 149 & 58.2 \\
$\Sigma$ & 16010 & 5765 & 17780 & 7419 & 12230 & 22520 & 9072 \\
\hline
\end{tabular}

Note: Toxic equivalency factors (TEF) defined by Nisbeth and LaGoy (Boström et al., 2002)

ILCR due to inhalation exposure to PAH at five ES and two PS were calculated according to USEPA methodology (using the mean concentration of each PAH), and the totals (i.e., sums) of ILCR are presented in Figure 2. These findings demonstrate that ILCR for 3- to 5-year-old students were significant from those of 6- to 10-year-old ones, with total $\sum$ ILCR 1-6-(at PS1) and 1-8 (PS2)-fold lower than at 5 ES. Finally, $\sum$ ILCR were below the recommended USEPA level of 10-6 at all seven examined institutions and thus are considered negligible.

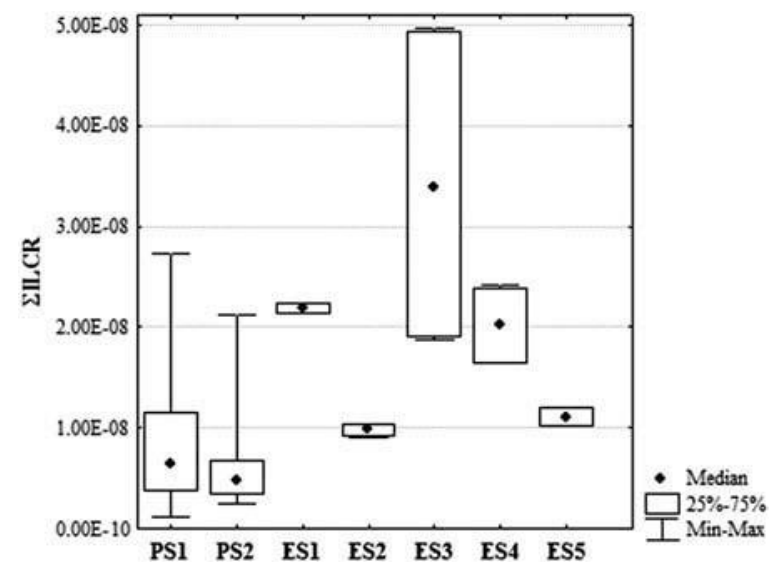

Figure 2. Incremental lifetime cancer risks (ILCR) for 3- to 5-year old and 6- to 10-year-old students at two preschools (PS1 and PS2) and five elementary schools (ES1-ES5). Values are sums of ILCR values of eight individual PAHs (naphthalene, chrysene, benz[a]anthracene, benzo[b]fluoranthene, benzo[k]fluoranthene, indeno[1,2,3-cd]pyrene, benzo[a]pyrene, and dibenz[a,h]anthracene) both indoors and outdoors.

\section{Discussion}

The levels and risks due to inhalation exposure to PM2.5-bound $\mathrm{PAH}$ were examined at different educational settings, namely at two PS (students with 3-5 year old) and five ES (6-10 year old). 
Children regularly spend much of their daytime in nurseries, day care centers, kindergartens, and schools, and thus, the respective air indoor quality is important for healthy child development. Regarding information on PAH pollution in educational environments in USA or Asia, there is indeed much to be done as few investigations were conducted (Eiguren-Fernandez et al., 2007; Jyethi et al., 2014; Ruchirawat et al., 2006, 2007; Tuntawiroon et al., 2007). Most of the existing data originates from European schools (Alves et al., 2014; Carpenter \& Bushkin-Bedient, 2013; Cirillo et al., 2006; Jovanović et al., 2014; Krugly et al., 2014; Moshammer \& Neuberger, 2003; Romagnoli et al., 2014; Rufo et al., 2015; Slezakova et al., 2015). Further, dissimilar study designs (in terms of PAH congeners and/or PM fractions considered) con- found the reported findings. Specifically, for the PS environment, particulate (PM2.5) PAH were in a range of $0.4-1.8 \mathrm{ng} / \mathrm{m} 3$ in PS in Southern California (Eiguren-Fernandez et al., 2007). For ES

(in Europe), the reported data varied between highly polluted indoor air of schools in post-communist countries (indoor PM2.5-bound PAHs in range of 20.1-131 ng/m3 in Lithuania; Krugly et al., 2014) to lower (and similar to this study) indoor PAH pollu- tion in schools located in Rome (Italy) (1.6-16 ng/ m3, Cirillo et al., 2006; 0.3-8.3 ng/m3, Romagnoli et al., 2014).

From the health point of view, it should be noted that at PS indoor PAH content mostly com- prised of congeners with 5-6 rings, in agreement with prior studies on indoor air quality in homes in Porto (Castro et al., 2011; Slezakova et al., 2009, 2014a). With the increasing number of the aro- matic rings, toxicity of the PAH rises; 5-6 rings PAH are thus among the most health relevant compounds. PAH with 5-6 rings included in this investigation (except for benzo[ghi]perylene) are classified as human (probable and/or possible) carcinogens (benzo[a]pyrene: class 1; others 2A-2B) (IARC, 2010). The carcinogenic congeners comprised $21-56 \%$ of $\Sigma \mathrm{PAH}$ in indoor air of ES (mean of $42 \%$ ) twofold higher (53-78\%) at PS. These findings are relevant because behavior pat- terns of younger children differ from those of 6-10 year olds. It is well established that younger chil- dren are smaller, and thus, their breathing zones are closer to the floors and in higher risk of inhal- ing re-suspended dust from floors than elementary students. Secondly, 3- to 5-year-old students spend much of their school time on floor (playing, crawl- ing, during classes, during nap) and finally tend to put "everything" into their mouth thus enhancing their non-nutritive ingestion of suspended PM (Schüepp \& Sly, 2012).

In a view of health protection, WHO defined the priory indoor pollutants which include $\mathrm{PAH}$, but at this moment, there are no guidelines for schools or other type of educational environments (WHO, 2010). The only reference exists for naphthalene in indoor air $(10 \mu \mathrm{g} / \mathrm{m} 3)(\mathrm{WHO}, 2010)$. Naphthalene levels in seven educational institutions evaluated in this study ranged from $2.01 \times 10$ at PS1 to $0.431 \mathrm{ng} / \mathrm{m} 3$ at ES4 in accor dance with existing recommendation (WHO, 2010). However, data need to be interpreted cau- tiously as the reference value is set as annual guideline, and secondly, naphthalene is light mole- cular weight PAH, and therefore in air mostly found in the gas phase (Castro et al., 2011; Slezakova et al., 2011). 
Dibenz[a,h]anthracene (PAH with five aromatic rings) was the predominant $\mathrm{PAH}$ in ambient air at all seven institutions assessed in this study (approximately 25\% $\sum \mathrm{PAH}$ at PS, 20-28\% at ES). High abundance of this $\mathrm{PAH}$ is typically due to emissions from light-duty gasoline motor vehicles (Ravindra et al., 2008). Dibenz[a,h]anthracene was the predominant compound in indoor air at two PS and typically 2-3rd predominant compound found in indoor air at ES. These observations suggest that vehicular emissions might be a rele-

vant source to contribute to indoor $\mathrm{PAH}$ pollution in the examined institutions. In agreement, $\mathrm{I} / \mathrm{O}$ ratios of heavy molecular PAH were shown as an outdoor contributor of these congeners to indoor air, both at ES and PS. Further, in some cases, I/O values were lower than 0.5 demonstrating the pre- valence of outdoor origin. In contrast, $\mathrm{I} / \mathrm{O}$ ratios of $\mathrm{PAH}$ with 2-3 rings indicated a contribution from indoor sources at the studied ES and PS. According to the evidence provided by school, personnel possible sources of chemicals might be: utilization of artistic materials (solvents, paints, waxes), application and use of various cleaning agents, and use of candles during social gatherings and birthdays). Similar findings were reported elsewhere (Derudi et al., 2013; Krugly et al., 2014; Morawska et al., 2013).

Due to its general high abundance and toxicity factor (value of 5), dibenz[a,h]anthracene was by far the largest contributor to $\sum \mathrm{B}[\mathrm{a}] \mathrm{Peq}$, both indoors and in ambient air of both $\mathrm{PS}\left(93-94 \%\right.$ of $\left.\sum \mathrm{B}[\mathrm{a}] \mathrm{Peq}\right)$ and at all 5 ES (91-95\%). In contrast, benzo[a]pyrene, class 1 human carcinogen and the most studied $\mathrm{PAH}$, contributed approximately only $4-5 \%$ and $3-5 \%$ of $\sum \mathrm{B}[\mathrm{a}] \mathrm{Peq}$ at $\mathrm{PS}$ and $5 \mathrm{ES}$ respectively. Data thus indicate the importance of assessment of dibenz[a,h]anthracene as this com-pound is often omitted among health-relevant PAH (Okona-Mensah et al., 2005).

Lifetime lung cancer risks due to total, indoor and outdoor exposure to PAH at both PS and five ES exceeded the recommended guideline of 10 designated by WHO (Boström et al., 2002). Indoor and outdoor incremental lifetime cancer risks were below USEPA threshold of 10, both at all 5 ES and two PS. ILCR due to indoor exposure were,

respectively, 3- and 3-6-fold higher than outdoors for 3- to 5-year-old and 6- to 10-year-old students, mostly due the respective time patterns with 6-hr indoors versus 1-1.5-hr outdoors. Indoor ILCR represented $70-85 \%$ of the total risks at ES; these contributions were somewhat lower (60-75\%) at PS where students spent more time outdoors. It is noteworthy that during the time of this study 3- to 5year-old children spent their time outdoors mostly in the afternoon when exposure to atmospheric pollutants is often increased (Slezakova et al., 2014b; Wang et al., 2011). In addition, when performing intensive physical activities outside such as playing and running inhalation rate of children are increased (USEPA, 2008) thus potentially leading to enhanced particle deposition especially in the upper respiratory tract (Schüepp \& Sly, 2012). Finally, in a view of the high contributions of indoor ILCR, development and implementation of air quality guidelines for schools and educational settings are necessary in order to provide a healthy and safe environment for children. 
Thus, at the levels that PM-bound PAH were observed at the five ES and two PS, these might pose some risks for the population of students and school personnel. The risk estimations are based upon the monitoring and assessment of $\mathrm{PAH}$ in classrooms as students spent most of their school time there. However, the risks might be even greater if exposures in other rele- vant school microenvironments, potentially pol- luted by $\mathrm{PAH}$ such as entrance halls, connecting corridors and passages, and canteens, are consid- ered. Finally, exposure to $\mathrm{PAH}$ at non-school settings including homes, during a travel to/ from a school, or while playing outside may also be relevant for risk assessments.

\section{Acknowledgments}

This study was supported by European Union (FEDER funds through COMPETE) and National Funds (Fundação para a Ciência e Tecnologia) through projects UID/QUI/50006/2013, POCI-01-0145FEDER-007265 and POCI-01-0145-FEDER-006939, by the FCT/MEC with national funds and cofunded by FEDER in the scope of the P2020 Partnership Agreement. Additional financial support was provided by Fundação para Ciência e Tecnologia through project PTDC/DTP-SAP/1522/2012 (ARIA: How indoor air quality can affect children allergies and asthma) and fellowships SFRH/BPD/105100/2014 (Klara Slezakova) and SFRH/BD/80113/2011 (Marta Oliveira).

\section{Supplemental meterial}

Supplemental data for this article can be accessed at the publisher's website.

\section{References}

Abdel-Shafy, H. I., and Mansour, M. S. M. 2016. A review on polycyclic aromatic hydrocarbons: source, environmental impact, effect on human health and remediation. Egypt. J. Petroleum 25: 107-123.

Alves, C. A., Urban, R. C., Pegas, P. N., and Nunes, T. 2014.

Indoor/outdoor relationships between PM10 and associated organic compounds in a primary school. Aerosol Air Qual. Res. 14: 86-98.

Annesi-Maesano, I., Baiz, N., Banerjee, S., Rudnai, P., and Rive, S.; on behalf of the SINPHONIE Group. 2013. Indoor air quality and sources in schools and related health effects. J. Toxicol Environ. Health B 16: 491-550

Annesi-Maesano, I., Moreau, D., Caillaud, D., Lavaud, F., Le Moullec, Y., Taytard, A., Pauli, G., and Charpin, D. 2007. Residential proximity fine particles related to allergic sensitisation and asthma in primary school children. Resp.Med. 101: 1721-1729.

Bae, S., Pan, X.-C., Kim, S.-Y., Park, K., Ki, Y.-H., Kim, H.,and Hong, Y.-C. 2010. Exposures to particulate matter and polycyclic aromatic hydrocarbons and oxidative stress in schoolchildren. Environ. Health Persp. 118: 579-583. 
Berg, V., Kraugerud, M., Nourizadeh-Lillabadi, R., Olsvik, P. A., Skåre, U., Alestrøm, P., Ropstad, E., Zimmer, K. E., and Lyche, J. L. 2016. Endocrine effects of real-life mixtures of persistent organic pollutants (POP) in experimental models and wild fish. J. Toxicol. Environ. Health A 79: 538-548.

Boström, C. E., Gerde, P., Hanberg, A., Jernstrom, B., Johansson, C., Kyrklund, T., Rannug, A., Tornqvist, M., Victorin, K., and Westerholm, R. 2002. Cancer risk assessments, indicators, and guidelines for polycyclic aromatic hydrocarbons in the ambient air. Environ. Health Persp. 110: 451488.

Burtscher, H., and Schüepp, K. 2012. The occurrence of ultrafine particles in the specific environment of children. Paediatr. Respir. Rev. 13: 89-94.

Carpenter, D. O., and Bushkin-Bedient, S. 2013. Exposure to chemicals and radiation during childhood and risk for cancer later in life. J Adolesc. Health. 52(5 Suppl): S21-S29.

Castro, D., Slezakova, K., Oliva-Teles, M. T., Delerue-Matos, C., Alvim-Ferraz, M. C., Morais, S., and Pereira, M. C. 2009. Analysis of polycyclic aromatic hydrocarbons in atmospheric particulate samples by microwave-assisted extraction and liquid chromatography. J. Sep. Sci. 32: 501-510.

Castro, D., Slezakova, K., Delerue-Matos, C., Alvim-Ferraz, M. C. M., Morais, S., and Pereira, M. C. 2011. Polycyclic aromatic hydrocarbons in gas and particulate phases of indoor environments influenced by tobacco smoke: levels, phase distributions, and health risks. Atmos. Environ. 45:

1799-1808.

Chen, C., Zhao, B., Zhou, W. T., Jiang, X. Y., and Tan, Z. C. 2012. A methodology for predicting particle penetration factor through cracks of windows and doors for actual engineering application. Build. Environ. 47: 339-348.

Cirillo, T., Montuori, P., Mainardi, P., Russo, I., Triassi, M., and Amodio-Cocchieri, R. 2006. Multipathway polycyclic aromatic hydrocarbon and pyrene exposure among children living in Campania (Italy). J. Environ. Sci. Health A Toxicol. Hazard. Subst. Environ. Eng. 41: 2089-2107.

Cohen Hubal, E. A., Sheldon, L. S., Burke, J. M., McCurdy, T. R., Berry, M. R., Rigas, M. L., Zartarian, V. G., and Freeman, N. C. 2000. Children's exposure assessment: a review of factors influencing children's exposure, and the data available to characterize and assess that exposure.Environ. Health Persp. 108: 475-486.

Derudi, M., Gelosa, S., Sliepcevich, A., Cattaneo, A., Cavallo, D., Rota, R., and Nano, G. 2013. Emission of air pollutants from burning candles with different composition in indoor environments. Environ. Sci. Pollut. Res. 21: 4320-4330.

Dvorská, A., Komprdová, K., Lammel, G., Klánová, J., Plachá, H. 2012. Polycyclic aromatic hydrocarbons in background air in central Europe - seasonal levels and limitations for source apportionment. Atmos. Environ. 46: 147-154.

Eiguren-Fernandez, A., Avol, E. L., Thurairatnam, S., Hakami, M., Froines, J. R., and Miguel, A. H. 2007. Seasonal influence on vapor-and particle-phase polycyclic aromatic hydrocarbon 
concentrations in school communities located in southern California. Aerosol. Sci. Technol. 41: 438446.

Elabbas, L. E., Esteban, J., Barber, X., Hamscher, G., Nau, H., Bowers, W. J., Nakai, J. S., Herlin, M., Åkesson, A., Viluksela, M., Borg, D., and Håkansson, H. 2014. In utero and lactational exposure to a mixture of environmental contaminants detected in Canadian Arctic human populations alters retinoid levels inrat offspring with low margins of exposure. J. Toxicol. Environ. Health A 77: 223-245.

Foos, B., Marty, M., Schwartz, J., Bennett, W., Moya, J., Jarabek, A. M., and Salmon, A. G. 2008. Focusing on children's inhalation dosimetry and health effects for risk assessment: an introduction. J. Toxicol. Environ. Health A 71: 149-165.

Hornung, R. W., and Reed, L. D., 1990. Estimation of average concentration in the presence of nondetectable values. Appl. Occup. Environ. Hyg. 5: 46-51.

International Agency for Research on Cancer (IARC). 2002. Some traditional herbal medicines, some mycotoxins, naphthalene and styrene. IARC Monogr. Eval. Carcinog.Risk. Human 82: 1-556.

International Agency for Research on Cancer (IARC). 2010. Some non-heterocyclic polycyclic aromatic hydrocarbons and some related exposures. IARC Monogr. Eval. Carcinogen. Risk. Human 92: 1-853. Jovanović, M., Vučićević, B., Turanjanin, V., Živković, M., and Spasojević, V. 2014. Investigation of indoor and out- door air quality of the classrooms at a school in Serbia. Energy 77: 42-48.

Jyethi, D. S., Khillare, P. S., and Sarkar, S. 2014. Risk assess- ment of inhalation exposure to polycyclic aromatic hydro- carbons in school children. Environ. Sci. Pollut. Res. Int. 21: 366-378.

Krugly, E., Martuzevicius, D., Sidaraviciute, R., Ciuzas, D., Prasauskas, T., Kauneliene, V., Stasiulaitiene, I., and Kliucininkas, L. 2014. Characterization of particulate and vapor phase polycyclic aromatic hydrocarbons in indoor and outdoor air of primary schools. Atmos. Environ. 82: 298-306.

Madureira, J., Paciência, I., Ramos, E., Henrique Barros, H., Cristiana Pereira, C., Teixeira, J. P., and de Oliveira Fernandes, E., 2015. Children's health and indoor air qual- ity in primary schools and homes in Portugal-Study design. J. Toxicol. Environ. Health A 78: 915-930.

Mesquita, S. R., van Drooge, B. L., Barata, C., Vieira, N., Guimarães, L., and Piña, B. 2014. Toxicity of atmospheric particle-bound PAHs: an environmental perspective. Environ. Sci. Pollut. Res. Int. 21: 11623-11633.

Mielgo-Ayuso, J., Aparicio-Ugarriza, R., Castillo, A., Ruiz, E., Ávila, J. M., Aranceta-Batrina, J., Gil, A., Ortega, R. M., Serra-Majem, L., Varela-Moreiras, G., and González- Gross, M. 2016. Physical activity patterns of the Spanish population are mostly determined by sex and age: findings in the ANIBES study. PLoS One 11: e0149969.

Morawska, L., Afshari, A., Bae, G. N., Buonanno, G., Chao, C. Y. H., Hänninen, O., Hofmann, O., Isaxon, C., Jayaratne, E. R., Pasanen, P., Salthammer, P., Waring, M., and Wierzbicka, A. 2013. Indoor aerosols: from personal exposure to risk assessment. Indoor Air 23: 462-487.

Moshammer, H., and Neuberger, M. 2003. The active surface of suspended particles as a predictor of 
lung function and pulmonary symptoms in Austrian school children. Atmos. Environ. 37: 1737-1744. Okona-Mensah, K. W., Battershill, J., Boobis, A., and Fielder, R. 2005. An approach to investigating the importance of high potency polycyclic aromatic hydrocarbons (PAHs) in the induction of lung cancer by air pollution. Food Chem. Toxicol. 43: 1103-1116.

Oliveira, M., Slezakova, K., Delerue-Matos, C., Pereira, M. C., and Morais, S. 2015. Polycyclic aromatic hydrocarbons: levels and phase distributions in preschool microenviron- ment. Indoor Air 25: 557568.

Oliveira, M., Slezakova, K., Delerue-Matos, C., Pereira, M. C., and Morais, S. 2016a. Assessment of polycyclic aromatic hydro- carbons in indoor and outdoor air of preschool environments (3-5 years old children). Environ. Pollut. 208: 382-394.

Oliveira, M., Slezakova, K., Delerue-Matos, C., Pereira, M. C., and Morais, S. 2016b. Assessment of air quality in pre- school environments (3-5 years old children) with empha- sis on elemental composition of PM10 and PM2.5. Environ. Pollut. 214: 430-439.

Pampanin, D. M., Le Goff, J., Skogland, K., Marcucci, C. R., Birger Øysæd, K., Lorentzen, M., Jørgensen, K. B., and Sydnes, M. O. 2016. Biological effects of polycyclic aro- matic hydrocarbons $(\mathrm{PAH})$ and their first metabolic pro ducts in in vivo exposed Atlantic cod (Gadus morhua). J.

Toxicol. Environ. Health A 79: 633-646.

Pereira, M. C., Santos, R. C., and Alvim-Ferraz, M. C. M. 2007. Air quality improvements using European environ- ment policies: a case study of SO2 in a coastal region in Portugal. J. Toxicol. Environ. Health A 70: 347-351.

Qi, H., Li, W. L., Zhu, N. Z., Ma, W. L., Liu, L. Y., Zhang, F., Li, Y. F. 2014. Concentrations and sources of polycyclic aromatic hydrocarbons in indoor dust in China. Sci. Total Environ. 491-492:100-107.

Ravindra, K., Sokhi, R., and Grieken, R. V. 2008. Atmospheric polycyclic aromatic hydrocarbons: source attribution, emission factors and regulation. Atmos. Environ. 42: 2895-2921.

Romagnoli, P., Balducci, C., Perilli, M., Gherardi, M., Gordiani, A., Gariazzo, C., Gatto, M. P., and Cecinato, A. 2014. Indoor PAHs at schools, homes and offices in Rome, Italy. Atmos. Environ. 92: 51-59.

Ruchirawat, M., Navasumrit, P., Settachan, D., and Autrup, H. 2006. Environmental impacts on children's health in Southeast Asia: genotoxic compounds in urban air. Ann. NY Acad. Sci. 1076: $678-690$.

Ruchirawat, M., Settachan, D., Navasumrit, P., Tuntawiroon, J., and Autrup, H. 2007. Assessment of potential cancer risk in children exposed to urban air pollution in Bangkok, Thailand. Toxicol. Lett. 168: 200-209.

Rufo, J. C., Madureira, J., Paciência, I., Slezakova, K., Pereira, M. C., Pereira, C., Teixeira, J. P., Pinto, M., Moreira, A., and de Oliveira Fernandes, E. 2015. Exposure of children to ultrafine particles in primary schools in Portugal. J. Toxicol. Environ. Health A 78: 904-914. 
Samburova, V., Connolly, J., Gyawali, M., Yatavelli, R. L. N., Watts, A. C., Chakrabarty, R. K., Zielinska, B., Moosmüller, H., and Khlystov, A. 2016. Polycyclic aro- matic hydrocarbons in biomassburning emissions and their contribution to light absorption and aerosol toxicity. Sci. Total Environ. 568: 391-401.

Sánchez-Soberón, F., van Drooge, B. L., Rovira, J., Grimalt, J. O., Nadal, M., Domingo, J. L., and Schuhmacher, M. 2016. Size-distribution of airborne polycyclic aromatic hydrocar- bons and other organic source markers in the surroundings of a cement plant powered with alternative fuels. Sci.

Total Environ. 550: 1057-1064.

Sarigiannis, D. A., Karakitsios, S. P.,Zikopoulos, D., Nikolaki S., and Kermenidou, M. 2015. Lung cancer risk from PAHs emitted from biomass combustion. Environ. Res. 137: 147- 156.

Schüepp, K., and Sly, P. D. 2012. The developing respiratory tract and its specific needs in regard to ultrafine particulate matter exposure. Paediatr. Respir. Rev. 13: 95-99.

Shen, G., Wei, S., Zhang, Y., Wang, R., Wang, B., Li, W., Shen, H., Huang, Y., Chen, Y., Chen, H., Wei, W., and Tao, S. 2012. Emission of oxygenated polycyclic aromatic hydrocarbons from biomass pellet burning in a modern burner for cooking in China. Atmos. Environ. 60: $234-237$. Slezakova, K., Castro, D., Delerue-Matos, C., Alvim-Ferraz, M. C., Morais, S., and Pereira, M. C. 2013a. Impact of vehicular traffic emissions on particulate-bound PAHs: levels and associated health risks. Atmos. Res. 127: 141- 147.

Slezakova, K., Castro, D., Delerue-Matos, C., Alvim- Ferraz, M. C., Morais, S., and Pereira, M. C. 2011. Air pollution from traffic emissions in Oporto, Portugal: health and environmental implications. Microchem. J. 99: 51-59.

Slezakova, K., Castro, D., Delerue-Matos, C., Morais, S., and Pereira, M. C. 2014a. Levels and risks of particulate-bound PAHs in indoor air influenced by tobacco smoke: a field measurement. Environ. Sci. Pollut Res. Int. 21: 4492-4501.

Slezakova, K., Castro, D., Pereira, M. C., Morais, S., Delerue- Matos, C., and Alvim-Ferraz, M. C. M. 2009. Influence of tobacco smoke on the elemental composition of indoor particles of different sizes. Atmos. Environ. 43: 486-493.

Slezakova, K., Fonseca, J., Morais, S., and Pereira, M. C. 2014b. Ultrafine particles in ambient air of an urban area: dose implications for elderly. J. Toxicol. Environ. Health Part A 77: 827-8367.

Slezakova, K., Pires, J. C. M., Castro, D., Alvim-Ferraz, M. C. M., Delerue-Matos, C., Morais, S., and Pereira, M. C. 2013b. PAH air pollution at a Portuguese urban area: carcinogenic risks and sources identification. Environ. Sci. Pollut. Res. Int. 20: 3932-3945.

Slezakova, K., Texeira, C., Morais, S., and Pereira, M. C. 2015. Children's indoor exposures to (ultra)fine parti- cles in an urban area: comparison between school and home environments. J. Toxicol. Environ. Health Part A 78: 886-896.

Tuntawiroon, J., Mahidol, C., Navasumrit P., Autrup, H., and Ruchirawat, M. 2007. Increased health risk 
in Bangkok children exposed to polycyclic aromatic hydrocarbons sources. Carcinogenesis 28: 816-822.

United States Environmental Protection Agency (USEPA). 1989. Risk Assessment Guidance for Superfund, Vol. I: Human Health Evaluation Manual. EPA/540/1-89/002, Washington, DC: Office of Emergency and Remedial Response.

United States Environmental Protection Agency (USEPA). 1990. Compendium of Methods for the Determination of Air Pollutants in Indoor Air. EPA/600/4-90/010 Research Triangle Park, NC: Atmospheric Research and Exposure Assessment Laboratory, US Environmental Protection Agency.

United States Environmental Protection Agency (USEPA). 2008. Child-Specific Exposure Factors Handbook. Washington, DC: National Center for Environmental Assessment, Office of Research and Development.

United States Environmental Protection Agency (USEPA). 2016. Risk-based concentration table. Available at http://www.epa.gov/reg3hwmd/risk/human/rb-concen tration_table/usersguide.htm (accessed May 2016).

Wang, Y., Hopke, P. K., Chalupa, D. C., and Utell, M. J. 2011. Long-term study of urban ultrafine particles and other pollutants. Atmos. Environ. 45: 7672-7680.

World Health Organization (WHO). 1987. Air Quality Guidelines for Europe. Copenhagen, Denmark: WHO Regional Office for Europe.

World Health Organization (WHO). 2000. Air Quality Guidelines for Europe - 2nd edition. Copenhagen, Denmark: WHO Regional Office for Europe.

World Health Organization (WHO). 2010. WHO Guidelines for Indoor Air Quality: Selected Pollutants. Copenhagen, Denmark: Regional Office for Europe of the World Health Organization.

World Health Organization (WHO). 2013. State of the Science of Endocrine Disrupting Chemicals 2012. Geneva: United Nations Environment Programme and the World Health Organization.

Wu, F., Liu, X., Wang, W., Man, Y. B., Chan, C. Y. L., Liu, W., Tao, S., and Wong, M. H. 2015. Characterization of parti- culate-bound PAHs in rural households using different types of domestic energy in Henan Province, China. Sci. Total Environ. 536: 840-846. 